\title{
Logiczna analiza wypowiedzi dotyczących braku pozytywnych i negatywnych odpowiedzi
}

\author{
Logical analysis of language samples \\ regarding lack of positive and negative responses
}

\author{
Włodzimierz Lapis \\ Instytut Językoznawstwa, Uniwersytet im. Adama Mickiewicza \\ ul. Międzychodzka 5, 60-371 Poznań \\ wlodzimierz@lapis.pl
}

\begin{abstract}
Ninety-nine statements concerning the lack of positive or negative reply were gathered from Polish Internet sites in this article and they were analysed in terms of their logical meaning (whether they denoted acceptance or lack of it). We also analysed in which situations we are dealing with such coincidences and what exactly is the touchstone that enables us to take this classification decision.
\end{abstract}

\section{Metoda pozyskania danych do analizy}

W artykule (Lapis 2006) dokonano interpretacji kategorii braku odpowiedzi w świadomości rozmówców. Zbadano i opisano, co denotują wypowiedzi, zawierające wyrażenia brak odpowiedzi jest, brak odpowiedzi oznacza i brak odpowiedzi nie. Były to wypowiedzi o szerszym znaczeniu od tych, których analizę przeprowadza się w niniejszym artykule. Rozważa się tu bowiem, co oznacza brak konkretnego typu wypowiedzi - pozytywnej czy też odmownej.

Podobnie jak w przypadku artykułu (Lapis 2006), materiały do badań zebrane zostały z polskich zasobów Internetu za pomocą wyszukiwarki www.szukacz.pl (pod koniec XI 2003 r.). Wybór takiej metody podyktowany został dwoma względami:

$>$ łatwym dostępem do materiałów badawczych dzięki możliwości pobierania ich z Internetu za pomoca jednej z wyszukiwarek internetowych,

> zamiarem dokonania analizy naturalnych wypowiedzi, w których to realizowane jest rozumienie interesujących zagadnień przez twórców owych wypowiedzi.

W poniższej tabeli 1 znajduje się zestawienie krotności wystapień $\mathrm{w}$ polskich zasobach Internetu poszczególnych wyrażeń, będących połączeniem (konkatenacją):

$>$ zwrotu: brak odmowy, brak zaprzeczenia, brak negacji (I typ) lub zwrotu: brak zgody, brak akceptacji brak potwierdzenia (II typ)

$>$ ze słowem: to, jest, oznacza lub nie.

Wyniki poszukiwań w polskich zasobach Internetu tak zdefiniowanych wyrażeń ze zwrotami I typu okazały się niezadowalające (po zero pomyślnych odpowiedzi w wyszukiwarce), dodatkowo 
sprawdzono ogólną liczbę wystąień w polskich zasobach Internetu samych poszczególnych zwrotów (tak I, jak i II typu; ich liczę podano w kolumnie „razem”). Liczby konkretnych wyszukiwań podano kursywą.

Tabela 1

\begin{tabular}{|c|c|c|c|c|c|c|c|}
\hline \multirow[b]{2}{*}{ typ } & \multirow[b]{2}{*}{ zwroty } & \multicolumn{4}{|c|}{ w konkatenacji z } & \multirow[b]{2}{*}{ razem } & \multirow{2}{*}{$\begin{array}{l}\text { suma wyników } \\
\text { kolumny „razem” }\end{array}$} \\
\hline & & to & jest & oznacza & nie & & \\
\hline \multirow{3}{*}{ I } & brak odmowy & 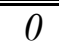 & 0 & 0 & 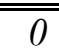 & 1016 & \multirow{3}{*}{29} \\
\hline & brak zaprzeczenia & 0 & 0 & 0 & 0 & 4 & \\
\hline & braknegacji & 0 & 0 & 0 & 0 & 9 & \\
\hline \multirow{4}{*}{ II } & brakzgody & 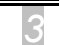 & $\overline{3}$ & 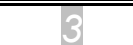 & $\overline{99}$ & 1578 & \multirow{3}{*}{3.910} \\
\hline & brak akceptacii & 7 & 16 & 1 & 4 & 1494 & \\
\hline & brak potwierdzenia & 2 & 5 & 17 & 0 & 838 & \\
\hline & SUMA: & 12 & 24 & 21 & 13 & 3.939 & 3.939 \\
\hline
\end{tabular}

Wystąpień wyrażeń II typu jest $3910 / 29 \approx 135$ razy więcej niż ma to miejsce ze zwrotami I typu. Jest to w pełni zrozumiałe, gdyż zazwyczaj oczekuje się potwierdzenia, a nie zanegowania (odbiorcy wypowiedzi łatwiej jest zrozumieć sformułowanie brak zgody od sformułowania brak odmowy).

Aby zachować pewną równowagę pomiędzy liczebnością rozważanych typów - do szczegółowej analizy wykorzystano wszystkie zwroty I typy (29) i wyrażenie II typu (tj. zwroty II typu z dodanym słowem to, jest, oznacza lub nie; w sumie jest ich $12+24+21+13=70$ ). Zatem analizowanych wypowiedzi jest: $29+70=99$. W powyższej tabeli są to wszystkie sytuacje, których liczebność podano w inwersie. Tworzą w niej one 15 kategorii, w tym 14 niepustych.

\section{Analiza konkretnych przypadków}

W poniższej, obszernej tabeli 2 wypisano w odpowiednio szerokim kontekście 99 badanych sytuacji, aby można było w pełni zrozumieć ich znaczenie. Główną kwestią jest tu określenie ich typu logicznego, tj. czy dla odbiorcy oznaczają one potwierdzenie (co w kolumnie „typ log.” oznaczono: +), zaprzeczenie (oznaczenie: -), czy też są pod tym względem neutralne (oznaczenie: 0). Celem oddania braku możliwości rozeznania typu logicznego (chociażby z tego powodu, że rozpatrywane wyrażenie czy zwrot wystąpiły w pytaniu, które - jak wiadomo - nie posiada wartości logicznej), zastosowano znak zapytania (?). Przydzielenie znaczeń zostało dokonane w oparciu o subiektywne odczucie autora niniejszego artykułu. W tabeli 2 wyróżniono też sytuacje pośrednie między neutralnością a zaprzeczeniem (0/-) oraz między neutralnością a potwierdzeniem $(0 /+)$. Przy takiej właśnie ich klasyfikacji zastosowano bardziej obiektywne kryteria:

$>$ jeśli wypowiedź jest na tak $(+)$ lub na nie (-), jednak w tekście są słowa umniejszające wartość tego znaczenia - jak np. niektórzy (niekoniecznie wszyscy) lub mógt (niekoniecznie zrobił), wówczas jest ona redukowana odpowiednio do „raczej tak” (oznaczenie: 0/+) i „raczej nie” (oznaczenie: 0/-),

$>$ jeśli tekst bezpośrednio nie mówi o tym jak jest (+ czy -), jednak mówi o pewnych okolicznościach, które na to wskazują, to również nadano im oznaczenia odpowiednio: 0/+ i $0 /-$.

W tabeli tej, w poszczególnych wypowiedziach:

$>$ słowa oznaczające ich kategorię zapisano w inwersie, celem łatwego zlokalizowania,

$>\mathrm{w}$ nawiasach pochyłych (/../) podano niezbędne dopowiedzenia, celem lepszego zrozumienia lub podania źródła ich pochodzenia,

$>$ symbol (...) oznacza opuszczenie nieistotnej części wypowiedzi,

$>$ znak • oznacza wypunktowanie,

$>$ podkreślenie słowa oznacza:

$>$ w przypadku kategorii bez „nie”, że ma ono znaczenie ilościowo wartościujące (np. słowa niektórzy, tylko, ...), 
w przypadku kategorii z „nie” - jeśli jest to jedno ze słów: to, jest lub oznacza (a więc tych, które były brane jako ostatnie w wyrażeniach $\mathrm{z}$ tabeli 1 ).

Z kolei w kolumnie „liczba” podano liczbę wskazań wyszukiwarki wystapień danych wypowiedzi w polskich zasobach Internetu, a jeśli dana wypowiedź dotyczy prawa - wówczas jej numer (w kolumnie LP) oznaczono w inwersie.

Wypowiedzi zawarte $\mathrm{w}$ tabeli 2 obarczone są pewnymi błędami językowymi (stylistyka, odmiana). Jest to podyktowane ich genezą. Nie przeprowadzono przy tym ich korekty, celem zachowania oryginalności (aby badać rzeczywistość).

Tabela 2

\begin{tabular}{|c|c|c|c|c|}
\hline $\begin{array}{l}\text { kate- } \\
\text { goria }\end{array}$ & LP & wypowiedź & $\begin{array}{l}\text { typ } \\
\text { log. }\end{array}$ & liczba \\
\hline \multirow[t]{7}{*}{$\begin{array}{l}\text { brak } \\
\text { od- } \\
\text { mowy }\end{array}$} & 1 & $\begin{array}{l}\text { Pierwszego razu odmówić nie wypada (wg zasad bon-tonu). Ale co } \\
\text { dalej? Chłopak (lub dziewczyna) bierze nasz brak odmowy za dobrą } \\
\text { monetę i nakręca się na dalsze tańcowanie, a nam to wcale nie w smak. }\end{array}$ & + & 3 \\
\hline & 2 & Dodatkową korzyścią /technologii GPRS/ jest brak odmowy połączenia. & $0 /+$ & 1 \\
\hline & 3 & $\begin{array}{l}\text { Bezskuteczność i zaskarżanie czynności upadłego uregulowano w art. } \\
54 \text { ust. } 1 \text { prawa upadłościo- wego, który stanowi: „Czynności prawne } \\
\text { pod tytułem darmym, a że przedmiotem jest mienie pań- stwowe, więc } \\
\text { ekonomiczny właściciel, jakim jest państwo, zastrzega sobie prawo } \\
\text { niewyrażenia zgo- dy na ich dokonanie. To samo zachowanie dotyczy } \\
\text { wspomnianej sprzedaży udziałów lub akcji. Jest na to miesiąc od dnia } \\
\text { otrzymania zgłoszenia o zamiarze dokonania czynności. Milczenie } \\
\text { rzadko wy- wołuje w prawie cywilnym skutki prawne, tutaj brak } \\
\text { odmowy zgody w terminie miesięcznym (ter- min zawity) powoduje, że } \\
\text { przedsiębiorstwo państwowe może dokonać zamierzonej czynności. } \\
\text { (...)” }\end{array}$ & + & 2 \\
\hline & 4 & $\begin{array}{l}\text { 5. Brak odmowy wydania zgody na zmianę listy w terminie określonym } \\
\text { w ust. } 4 \text { jest równoznaczny z przyjęciem zmian listy. /USTAWA z dnia } \\
27 \text { sierpnia } 2003 \text { r. o zmianie ustawy o organizacji i funkcjonowaniu } \\
\text { funduszy emerytalnych oraz niektórych innych ustaw (Dz. U. Nr 170, } \\
\text { poz. 1651) Art. 58./ }\end{array}$ & + & 2 \\
\hline & 5 & $\begin{array}{l}\text { 6. W przypadku wyrobów medycznych zaliczanych do klasy III oraz } \\
\text { wyrobów medycznych implan- towanych i inwazyjnych, których czas } \\
\text { ciagłego użycia przekracza } 30 \text { dni, należących do klas IIa lub IIb, brak } \\
\text { odmowy wydania pozwolenia na rozpoczęcie badań klinicznych w ciageu } \\
60 \text { dni od dnia złożenia wniosku o pozwolenie na rozpoczęcie badań } \\
\text { klinicznych jest równoznaczny z udzieleniem pozwolenia. /USTAWA } \\
\text { z dnia } 27 \text { lipca } 2001 \text { r. o wyrobach medycznych. (Dz. U. Nr 126, poz. } \\
\text { 1380) Art. 24./ }\end{array}$ & + & 4 \\
\hline & 6 & $\begin{array}{l}\text { Poniżej podane zostały przykładowe warunki jakie musi spełnić } \\
\text { kontrahent, aby mógł być objęty limitem automatycznym } \\
\text { /ubezpieczenia finansowego/: • brak informacji uzasadniających } \\
\text { nieudzielenie kredytu kupieckiego, • brak odmowy ubezpieczenia dla } \\
\text { limitu indywidualnego, (...) }\end{array}$ & $0 /+$ & 1 \\
\hline & 7 & $\begin{array}{l}\text { Dlatego pytam pana o tę wypowiedź, bo zastanawiam się, czy czasem } \\
\text { Lew Rywin nie próbował o- siagną́ prezesury stacji w kontaktach z } \\
\text { panem i brak odmowy spowodował tak niepochlebne opinie. }\end{array}$ & $?$ & 3 \\
\hline $\begin{array}{l}\text { brak } \\
\text { za- }\end{array}$ & 8 & $\begin{array}{l}\text { Izrael nie ustosunkował się nigdy do rewelacji gazety; brak zaprzeczenia } \\
\text { niektórzy uznali za pośrednie potwierdzenie. }\end{array}$ & $0 /+$ & 1 \\
\hline
\end{tabular}




\begin{tabular}{|c|c|c|c|c|}
\hline \multirow[t]{3}{*}{$\begin{array}{l}\text { prze- } \\
\text { czenia }\end{array}$} & 9 & $\begin{array}{l}\text { W powyższym uwidaczniają się dwie rzeczy: • brak zaprzeczenia } \\
\text { prawdziwości tekstu • wynikiem trzęsienia ziemi „skały się } \\
\text { rozpadały”, a nie „groby się otwierały”. }\end{array}$ & 0 & 1 \\
\hline & 10 & $\begin{array}{l}\text { Chcę jednak zwrócić uwagę, że najbardziej przerażający jest nie } \\
\text { przypadek poznański - tylko wiele rzeczy które się działy wokół: • } \\
\text { cudowna kariera roznosiciela „rzymskich” majtek, Nuncjusz } \\
\text { denuncjujący tych co zgłosili przypadek w trosce o dobro Kościoła, } \\
\text { Hierarcha spokojnie oświadczający, że sprawa na Synodzie była znana, } \\
\text { • brak zaprzeczenia ze strony wszystkich innych Hierarchów, zdrada w } \\
\text { strukturach kościelnych i przekazywanie informacji różowym. }\end{array}$ & 0 & 1 \\
\hline & 11 & $\begin{array}{l}\text { Chłopak nie mógł znieść dłużej tego pełnego żalu spojrzenia, odwrócił } \\
\text { zatem wzrok w stronę nauczycielki. Wyglądała jak posag. Stała } \\
\text { wyprostowana (...). Kiedy chłopak zapytał ją, czy może wyjść na } \\
\text { chwilę kupić napój, bowiem zaschło mu w gardle, nie zareagowała, } \\
\text { podobnie jak nikt z klasy. Tomek milczenie przyją jako brak } \\
\text { zaprzeczenia i pospiesznie opuścił pomieszczenie lekcyjne, kierując się } \\
\text { w stronę jednej z toalet. }\end{array}$ & + & 1 \\
\hline \multirow{5}{*}{$\begin{array}{l}\text { brak } \\
\text { nega- } \\
\text { cji }\end{array}$} & 12 & Przecież brak negacji niczego nie przesądza. & 0 & 2 \\
\hline & 13 & $\begin{array}{l}\text { Jest jednak proste rozwiązanie bez przebudowy płytki. Wystarczy } \\
\text { zamienić tranzystor npn na pnp w ten sposób, że zamieniamy kolektor } \\
\text { z emiterem, baza pozostaje bez zmian. (...) Korzyścią tego rozwiązania } \\
\text { jest też brak negacj! }\end{array}$ & 0 & 2 \\
\hline & 14 & $\begin{array}{l}\text { Postrzegamy świat przez brak negacj; kategoria negacji to częstość } \\
\text { występowania sylaby nie- w wyrazach pozytywnych /porady ogólne } \\
\text { jak przemawiać/ }\end{array}$ & 0 & 3 \\
\hline & 15 & $\begin{array}{l}\text { Brak negacj, poza stratą i zyskiem, brak pragnienia czy przywiązania - } \\
\text { taka jest medytacja }\end{array}$ & 0 & 1 \\
\hline & 16 & $\begin{array}{l}\text { dwie negacje to brak negacj, więc czy na pewno zdjęcie ci się nie } \\
\text { podoba;)) }\end{array}$ & 0 & 1 \\
\hline \multirow[t]{3}{*}{$\begin{array}{l}\text { brak } \\
\text { zgody } \\
\text { to }\end{array}$} & 17 & $\begin{array}{l}\text { W porównaniu z sondażami z poprzednich miesięcy wzrosła akceptacja } \\
\text { dla obecnej prezydentury /Aleksandra Kwaśniewskiego/ ze strony } \\
\text { zwolenników ,S”. Z pozostałych grup, stosunkowo naj- mniej } \\
\text { zastrzeżeń mają osoby najstarsze, najsłabiej wykształcone, o } \\
\text { najniższych zarobkach, prywatni przedsiębiorcy. Brak zgody to z kolei } \\
\text { najczęstsza postawa wśród ludzi z wyższym wykształceniem, } \\
\text { pracujących w przedsiębiorstwach państwowych, bezrobotnych, } \\
\text { piastujących wysokie stanowiska. }\end{array}$ & $0 /-$ & 1 \\
\hline & 18 & Jak brak zgody, to bez zgody /śródtytuł/ & - & 1 \\
\hline & 19 & $\begin{array}{l}\text { Artykuł } 197 \text { § } 1 \text { k.k. (art. } 168 \text { § } 1 \text { d.k.k.) - przestępstwo zgwałcenia } \\
\text { popełnione może być wtedy i tylko wtedy, gdy pokrzywdzony nie } \\
\text { wyraził zgody na zachowanie sprawcy. Brak zgody to zarówno brak } \\
\text { pozytywnej decyzji, jak również wyrażenie decyzji negatywnej. Wyraz } \\
\text { temu, że brak zgody pokrzywdzonego jest niezbędnym znamieniem } \\
\text { tego czynu, dał Sąd Apelacyjny w wyroku z dnia } 01.03 .1995 \text { r. (II AKr } \\
548 / 94 \text {, Prok. i Pr. 1996, nr 6): - Takie elementy, jak: rzeczywistość } \\
\text { oporu pokrzywdzonej, świadomość sprawcy, brak nawet dorozumianej } \\
\text { zgody należą przede wszystkim do znamion czynu zabronionego } \\
\text { przewidzianych w art. } 168 \text { k.k. }\end{array}$ & - & 1 \\
\hline
\end{tabular}




\begin{tabular}{|c|c|c|c|c|}
\hline \multirow[t]{3}{*}{\begin{tabular}{|l|} 
brak \\
zgody \\
jest
\end{tabular}} & 20 & $\begin{array}{l}\text { Warto przytoczyć również Wyrok Naczelnego Sądu } \\
\text { Administracyjnego z dnia } 29 \text { marca } 1990 \text { r. (sygn. Akt IV SA 33/90) } \\
\text { zgodnie z którym nadbudowa kondygnacji nad budynkiem } \\
\text { stanowiącym współwłasność jest czynnością przekraczającą zakres } \\
\text { zwykłego zarządu i wymaga zgody współwłaściciela albo } \\
\text { zastępującego tę zgodę orzeczenia sądu. Brak zgody jest równoznaczny z } \\
\text { brakiem prawa do dysponowania nieruchomością. }\end{array}$ & - & 1 \\
\hline & 21 & $\begin{array}{l}\text { Warto zwrócić uwagę, że nie wydano zgody Michałowi Machlejdzie na } \\
\text { objęcie stanowiska prezesa zarządu BGŻ. Na stanowisko to wybrała go } \\
31 \text { sierpnia br. rada BGŻ. Jednak, według nie potwier- dzonych } \\
\text { informacji, brak zgody jest efektem niedostarczenia w terminie } \\
\text { wszystkich wymaganych papierów. }\end{array}$ & 0 & 1 \\
\hline & 22 & $\begin{array}{l}\text { Art. } 12 \text { p. 4. Komitet Wykonawczy musi uzyskać wcześniejszą zgodę } \\
\text { Zgromadzenie Ogólnego odnośnie: (...) • zawierania umów, w których } \\
\text { stowarzyszenie jest gwarantem długu, dużnikiem solidarnym bądź } \\
\text { ograniczonym, gdy stowarzyszenie udziela gwarancji osobom trzecim, } \\
\text { albo wtedy gdy przyjmuje odpowiedzialność za dług osób trzecich; } \\
\text { brak zgody jest nieskuteczny wobec osób trzecich. /statut stowarzyszenia } \\
\text { TERENA/ }\end{array}$ & - & 1 \\
\hline \multirow[t]{3}{*}{$\begin{array}{l}\text { brak } \\
\text { zgody } \\
\text { ozna- } \\
\text { cza }\end{array}$} & 23 & $\begin{array}{l}\text { Eksperci wyliczyli, że jeśli panie z All Saints nie pogodzą się, to } \\
\text { rozpad zespołu może ich koszto- wać pięć milionów funtów (prawie } 33 \\
\text { miliony złotych). /ze względu na zerwanie trasy koncertowej/ Gazeta } \\
\text { The Sun, doniosła, że podczas spotkania z prawnikami, dziewczyny } \\
\text { zostały poinformowane, że brak zgody oznacza że stracą po } 1,2 \text { miliona } \\
\text { funtów od łepka (ponad } 8 \text { milionów złotych). }\end{array}$ & - & 1 \\
\hline & 24 & $\begin{array}{l}\text { PYT: czemu nie można zmienić zdania na temat zezwolenia na } \\
\text { publikacje danych? ODP: Co do te-go zdania - nie zamieszczałem tej } \\
\text { opcji jako dostępnej do zmiany, bo brak zgody oznacza przymus } \\
\text { usunięcia danych z Gildii. Po prostu wkrótce dodam opcję „Usuń moje } \\
\text { dane z Ksiąg Gildii”. }\end{array}$ & - & 1 \\
\hline & 25 & $\begin{array}{l}\text { Po czwarte, pewne ustawy - zwłaszcza konstytucyjne, związane z } \\
\text { federalnym charakterem Austrii i inne, wspomniane w kilku } \\
\text { szczegółowych przepisach konstytucyjnych wymagają zgody drugiej } \\
\text { izby. (...) Brak zgody oznacza oczywiście niedojście ustawy do skutku. }\end{array}$ & - & 1 \\
\hline $\begin{array}{l}\text { brak } \\
\text { akce- } \\
\text { ptacji } \\
\text { to }\end{array}$ & 26 & $\begin{array}{l}\text { Dziękowanie Bogu w każdej sytuacji oznacza uznanie i } \\
\text { zaakceptowanie Jego suwerenności i mą- drości. Jest to jedyny sposób } \\
\text { na zdobycie Bożej mądrości, która pomoże nam w trudnych chwilach. } \\
\text { Brak dziękczynienia oznacza brak akceptacji. A brak akceptacji to } \\
\text { odrzucenie. Kiedy odrzucamy kłopoty i zmiany, odcinamy się od } \\
\text { możliwości uzyskania Bożej pomocy. Tylko akceptacja otwiera nam } \\
\text { drzwi do Bożej madrości. To znaczy, tylko wtedy, gdy przyjmiemy } \\
\text { sytuację jako pochodzącą od Niego, Bóg natychmiast pozwala nam } \\
\text { zrozumieć sytuacje, w której sie znaleźliśmy. }\end{array}$ & - & 1 \\
\hline
\end{tabular}




\begin{tabular}{|c|c|c|c|c|}
\hline & 27 & $\begin{array}{l}\text { Wszystkie tradycje namawiają do zaprzestania kombinowania w } \\
\text { głowach na temat znaczenia życia i zadawania tego bezsensownego } \\
\text { pytania: Dlaczego? Jeżeli uda ci się uspokoić umysł na tyle, by do- } \\
\text { trzeć do miejsca akceptacji - to nagle te wszystkie otaczające cię burze, } \\
\text { te pragnienia, te niezadowo- lenia, (w końcu umysł ma to do siebie, że } \\
\text { jest stale niezadowolony) - ta energia wypala się, uspokaja, przycicha. } \\
\text { Wtedy możesz skontaktować się ze swoim prawdziwym wewnętrznym } \\
\text { jestestwem i możesz zacząć dostrzegać, co jest prawdziwe, co jest } \\
\text { rzeczywiste. Co wymaga zmiany - a co trzeba zostawić tak jak jest? } \\
\text { Akceptacja jest tak prosta - to przecież tylko opinia. Brak akceptacji to } \\
\text { też tylko opinia. JEST TAK JAK JEST. Jak dotrzesz do miejsca } \\
\text { akceptacji - jesteś absolutnie wolny. Możesz spokojnie patrzeć na } \\
\text { kogoś z twojej rodziny, kto robi bezsensowne rzeczy i zamiast } \\
\text { próbować zmieniać tę osobę na siłę możesz po prostu powiedzieć } \\
\text { sobie: ONA JEST TAKA JAKA JEST. ON JEST TAKI JAKI JEST. } \\
\text { /warsztaty holistyczne Ewy Foley/ }\end{array}$ & 0 & 3 \\
\hline & 28 & $\begin{array}{l}\text { Spróbuję trochę uporządkować sobie motywy stosowania masek. Bo } \\
\text { wielki wór pod tytułem „brak akceptacj” to taki ogólnik. Tym bardziej że } \\
\text { często wcale mi nie chodzi o lubienie mnie dla samego lubienia, ale } \\
\text { jest to „narzędzie”, bywa, że mam w tym interes i to jest najzwyklejsza } \\
\text { manipulacja. Jeśli ktoś nas polubi, to jest większa szansa, że zrobi coś } \\
\text { lub łatwiej będzie się dogadać, załatwić jakąś sprawę. Trudno odmówić } \\
\text { komuś, kogo lubimy, prawda? /forum/ }\end{array}$ & 0 & 3 \\
\hline $\begin{array}{l}\text { brak } \\
\text { akce- } \\
\text { ptacji }\end{array}$ & 29 & $\begin{array}{l}\text { Jak myślicie z czego rodzą się kompleksy i jak sobie z nimi radzić? } \\
\text { Brak akceptacji jest głównym prowodyrem....krytyka.....a o sposobach } \\
\text { sama chciałabym się czegoś dowiedzieć. }\end{array}$ & $0 /-$ & 6 \\
\hline jest & 30 & $\begin{array}{l}\text { Wiele razy byłem świadkiem sytuacji, w których osoba gorzej lub } \\
\text { nawet inaczej ubrana padała ofiarą zbiorowych drwin, przezwisk... } \\
\text { Często nie potrafiła „doczepić” się do towarzystwa. Nierzadko, przez } \\
\text { większość czasu pozostawała na uboczu. Taki brak akceptacji jest } \\
\text { normalny u zwierzątek popularnie zwanych ludźmi. Patrząc na nich z } \\
\text { perspektywy można powiedzieć, że ich zachowanie jest bezsensowne. } \\
\text { Gdyby koty, zwracając szczególną uwagę na ich różnorodność i stan } \\
\text { futra, zachowywały się w ten sposób, ponad połowa populacji } \\
\text { popadłaby w depresję i straciła apetyt. }\end{array}$ & $0 /-$ & 1 \\
\hline & 31 & $\begin{array}{l}\text { Brak ostrożności jest błędem, ale brak życzliwości bywa jeszcze } \\
\text { większym. To rzucanie bumeranga- mi. Myślę, że bywają sytuacje gdy } \\
\text { bycie nieżyczliwym jest konieczne, że zdecydowany brak akceptacji jest } \\
\text { nawet pewnego rodzaju obowiązkiem, że nie ma czasu na coś inne, } \\
\text { bywają chwile kiedy trzeba podjąć szybkie decyzje. }\end{array}$ & $0 /-$ & 2 \\
\hline & 32 & $\begin{array}{l}\text { Społeczny krytycyzm i brak akceptacji jest pogłębiany rozpiętością .... } \\
\text { między oczekiwaniami a ich realizacją..., czyli przeświadczeniem, że } \\
\text { „nie tak miało być”. }\end{array}$ & $0 /-$ & 1 \\
\hline & 33 & $\begin{array}{l}\text { Każdy musi zapoznać się z regulaminem i go zaakceptować. Brak } \\
\text { akceptacji jest równoznaczny z rezygnacją z podłączenia. /Amatorska } \\
\text { Sieć Komputerowa Lnet/ }\end{array}$ & - & 1 \\
\hline & 34 & $\begin{array}{l}\text { Może Papież i Matka Teresa z Kalkuty to takie postacie, że nikt nie } \\
\text { miał wattpliwości, co do ich misji, nikt nie był i nie jest przeciwko? } \\
\text { Chociaż przeciwko Papieżowi jest bardzo dużo osób, więc owa niechęć } \\
\text { i niekiedy brak akceptacji jest czymś, z czym po prostu trzeba się liczyć. }\end{array}$ & $0 /-$ & 1 \\
\hline
\end{tabular}




\begin{tabular}{|c|c|c|c|c|}
\hline & 35 & $\begin{array}{l}\text { Zdaję sobie sprawę, że brak akceptacji dla dziecka /poczętego/ jest } \\
\text { wielkim dramatem i piekłem dla kobiety. I to nie tylko problem } \\
\text { teoretyczny. Ale mimo to uważam, że ten brak akceptacji jest o wiele } \\
\text { mniejszym piekłem niż rozwiązanie ostateczne polegające na } \\
\text { uśmierceniu maleństwa. }\end{array}$ & $0 /-$ & 1 \\
\hline & 36 & $\begin{array}{l}\text { W każdym zawodzie konieczny jest jakiś rodzaj akceptacji, szczególnie } \\
\text { w takim, jak nasz, przecież pracujemy dla publiczności, to ona nas } \\
\text { akceptuje albo nie. Dla aktora brak akceptacji jest ogromnie przykry, } \\
\text { wszystkie frustracje, stresy biorą się z jej braku, ze świadomości, że się } \\
\text { nie osiagnęło tego, co się zamierzało, że w jakiś sposób zawiodło się i } \\
\text { samego siebie. }\end{array}$ & $0 /-$ & 2 \\
\hline & 37 & Gorzej jest, gdy brak akceptacji jest raczej permanentny. & $0 /-$ & 1 \\
\hline $\begin{array}{l}\text { brak } \\
\text { akce- } \\
\text { ptacji } \\
\text { ozna- } \\
\text { cza }\end{array}$ & 38 & $\begin{array}{l}\text { Brak akceptacji oznacza konieczność debaty nad danym projektem na } \\
\text { posiedzeniu plenarnym. }\end{array}$ & $0 /-$ & 1 \\
\hline \multirow{2}{*}{$\begin{array}{l}\text { brak } \\
\text { po- } \\
\text { twier- } \\
\text { dze- } \\
\text { nia to }\end{array}$} & 39 & $\begin{array}{l}\text { Warunki moich aukcji 1. Allegrowicze poniżej *, powinni potwierdzić } \\
\text { złożenie oferty. Brak potwierdzenia to automatyczne usunięcie z licytacji. } \\
(\ldots)\end{array}$ & - & 1 \\
\hline & 40 & $\begin{array}{l}\text { Nasze zasady: 1. Osoby, które nie mają przynajmniej } 10 \text { pozytywów } \\
\text { proszone są o potwierdzenie udziału w aukcjach. } 2 \text {. Brak potwierdzenia } \\
\text { to automatyczne usunięcie z licytacji. 3. Po każdej wygranej aukcji } \\
\text { wymagam potwierdzenia Twojego adresu na e-mail. (...) }\end{array}$ & - & 1 \\
\hline \multirow{3}{*}{$\begin{array}{l}\text { brak } \\
\text { po- } \\
\text { twier- } \\
\text { dze- } \\
\text { nia } \\
\text { jest }\end{array}$} & 41 & $\begin{array}{l}\text { Każda ramka z danymi jest potwierdzana przez odbiorcę. Brak } \\
\text { potwierdzenia jest sygnalizowany w programie MuelTrans. } \\
\text { /Przeznaczenie i zasada działania programu MuelTrans./ }\end{array}$ & 0 & 1 \\
\hline & 42 & $\begin{array}{l}\text { 5. Sprzedawca w ciagu } 24 \text { godzin od otrzymania zamówienia } \\
\text { potwierdzi zamówienie u Kupującego drogą internetową lub } \\
\text { telefoniczną. Zamówienia potwierdzonego nie można anulować } 6 \text {. Brak } \\
\text { po- twierdzenia jest jednoznacznie traktowane z anulowaniem } \\
\text { zamówienia /regulamin aukcji interneto- wej/ }\end{array}$ & - & 3 \\
\hline & 43 & $\begin{array}{l}\text { Brak potwierdzenia jest równoznaczny z rezygnacją z udziału w turnieju } \\
\text { sportowym. }\end{array}$ & - & 1 \\
\hline \multirow{5}{*}{$\begin{array}{l}\text { brak } \\
\text { po- } \\
\text { twier- } \\
\text { dze- } \\
\text { nia } \\
\text { ozna- } \\
\text { cza }\end{array}$} & 44 & $\begin{array}{l}\text { Otrzymają Państwo potwierdzenie rezerwacji tą samą drogą. Brak } \\
\text { potwierdzenia oznacza że rezerwacja nie mogła zostać przyjęta /do } \\
\text { restauracji/. }\end{array}$ & - & 2 \\
\hline & 45 & $\begin{array}{l}\text { Warunki obowiązujące na moich aukcjach: (...) • udział w licytacji } \\
\text { należy potwierdzić mailem (brak potwierdzenia oznacza usunięcie } \\
\text { oferty...) (...) }\end{array}$ & - & 1 \\
\hline & 46 & $\begin{array}{l}\text { Każde zamówienie internetowe potwierdzamy e-mail'em. Brak } \\
\text { potwierdzenia oznacza że zamówienie do nas nie dotarło. }\end{array}$ & - & 1 \\
\hline & 47 & $\begin{array}{l}\text { Kandydaci przyjęci na I rok studiów zobowiązani są do potwierdzenia } \\
\text { zamiaru podjęcia nauki (...) Brak potwierdzenia oznacza rezygnację ze } \\
\text { studiów i powoduje skreślenie kandydata z listy osób kwalifikowanych } \\
\text { do przyjęcia na I rok studiów! }\end{array}$ & - & 1 \\
\hline & 48 & $\begin{array}{l}\text { 5. Zamówienia potwierdzane sa w ciagu } 48 \text { godzin roboczych od } \\
\text { momentu otrzymania zamówienia. O otrzymaniu zamówienia } \\
\text { informujemy listem e-mail na podany w formularzu adres. Brak potwier- } \\
\text { dzenia oznacza, że zamówienie nie zostało przyjęte do realizacji. } \\
\text { /regulamin serwisu internetowego/ }\end{array}$ & - & 1 \\
\hline
\end{tabular}




\begin{tabular}{|c|c|c|c|c|}
\hline & 49 & $\begin{array}{l}\text { Osoby, którym zostaną przyznane stypendia hospitacyjne będą } \\
\text { powiadomione przez Centralny Ośrodek Doskonalenia Nauczycieli. } \\
\text { Brak potwierdzenia oznacza nieprzyznanie stypendium. }\end{array}$ & - & 4 \\
\hline & 50 & $\begin{array}{l}\text { Ogłoszenie pełnych list kandydatów przyjętych na studia nastąpi } 4 \\
\text { lipca } 2003 \text { roku. Kandydaci przyjęci na I rok studiów zobowiązani są } \\
\text { do pisemnego potwierdzenia zamiaru podjęcia nauki na Uniwersytecie } \\
\text { do } 24 \text { lipca } 2003 \text { roku. Brak potwierdzenia oznacza rezygnację ze studiów } \\
\text { i powoduje skreślenie Kandydata z listy przyjętych. }\end{array}$ & - & 1 \\
\hline & 51 & $\begin{array}{l}\text { Poprawność naświetlenia jest potwierdzona przez zaświecenie się } \\
\text { zielonej lampki } 10 \text {. Brak potwier- dzenia oznacza że odległość jest poza } \\
\text { określonym zakresem dla danej wartości liczby przesłony. }\end{array}$ & - & 2 \\
\hline & 52 & $\begin{array}{l}\text { Na życzenie klienta wysyłamy pisemne potwierdzenie przyjęcia } \\
\text { zamówienia. Brak potwierdzenia oznacza pełną akceptację zlecenia oraz } \\
\text { jego realizację w sposób określony w zamówieniu }\end{array}$ & + & 1 \\
\hline & 53 & $\begin{array}{l}\text { Warunki uczestnictwa w wycieczkach (...) Uczestnik wycieczki jest } \\
\text { odpowiedzialny za zasieganie informacji u pilota lub z tablic ogłoszeń } \\
\text { w hotelu dotyczących organizowanych imprez oraz terminu podróży } \\
\text { powrotnej, w tym także zmian w stosunku do godziny podanej w } \\
\text { dowodzie uczestnictwa. Zalecane jest skontaktowanie się z lokalnym } \\
\text { przedstawicielem biura podróży na } 24 \text { godziny przed planowanym } \\
\text { powrotem w celu potwierdzenia godziny. Uczestnik wycieczki jest } \\
\text { ponadto odpowie- dzialny za przestrzeganie zasad potwierdzania } \\
\text { odcinków lotów, jakich powiadomi go biuro podróży. Brak potwierdzenia } \\
\text { oznacza, że linie lotnicze uczestniczące w transporcie mają prawo } \\
\text { rozdyspono- wać zarezerwowane miejsca. W takim przypadku } \\
\text { uczestnik wycieczki nie ma prawa wnosić rosz- czeń w stosunku do } \\
\text { biura podróży lub linii lotniczych z tytułu następstw niepotwierdzenia } \\
\text { przez niego lotu. (...) }\end{array}$ & - & 3 \\
\hline \multirow[t]{4}{*}{$\begin{array}{l}\text { brak } \\
\text { zgody } \\
\text { nie }\end{array}$} & 54 & $\begin{array}{l}\text { Tylko małżonek wyłącznie winny rozkładu pożycia małżeńskiego jest } \\
\text { uzależniony w kwestii rozwo- du od stanowiska współmałżonka. } \\
\text { Tylko w takiej sytuacji sąd nie da rozwodu przy sprzeciwie dru- giej } \\
\text { strony. W pozostałych przypadkach ten brak zgody nie jest decydujący a } \\
\text { Sąd ocenia po pierw- sze to czy doszło do całkowitego rozkładu } \\
\text { małżeństwa (brak więzi uczuciowej, pożycia fizycznego i więzi } \\
\text { gospodarczej) i czy rozkład ten jest trwały }\end{array}$ & 0 & 1 \\
\hline & 55 & $\begin{array}{l}\text { W szczególności zbycie udziału, jego części lub ułamkowej części } \\
\text { bądź też jego zastawienie może być uzależnione od zgody spółki. Jeżeli } \\
\text { tak - to zgody powinien udzielić zarząd w formie pisemnej (art. } 1823 \\
\text { k.s.h.). Brak zgody nie powoduje bezwzględnej nieważności, lecz } \\
\text { jedynie bezskuteczność zawieszoną (art. } 63 \text { kodeksu cywilnego). Jeśli } \\
\text { zgody odmówiono, pozwolenie na zbycie może wydać sąd rejestrowy, } \\
\text { gdy istnieją ważne powody. }\end{array}$ & 0 & 1 \\
\hline & 56 & $\begin{array}{l}\text { Brak zgody - nie ma prawa do odszkodowania /tytuł linku, dalej idzie:/ } \\
\text { Niżej wyjaśniamy, czy pracownik, przez nieprzyjęcie proponowanych } \\
\text { zmian treści umowy o pracę, może przyczynić się do rozwiązania } \\
\text { łączącego go z pracodawcą stosunku pracy. }\end{array}$ & $0 /+$ & 3 \\
\hline & 57 & $\begin{array}{l}\text { W przypadku braku zgody w jakiejś sprawie członkowie zespołu } \\
\text { wspólnie poszukują płaszczyzny porozumienia. Chwilowy brak zgody } \\
\text { nie wywołuje wśród nich uczucia dyskomfortu. }\end{array}$ & 0 & 1 \\
\hline
\end{tabular}


58 Projekt ustawy zakłada, że w określonym terminie użytkownicy wieczyści staną się z mocy prawa właścicielami, chyba że w ciagu 180 dni zgłoszą sprzeciw. Brak zgody nie wymagałby uzasadnienia. Przekształcenie użytkowania wieczystego we własność byłoby skuteczne 270 dni od daty wejścia w życie ustawy, a w ciągu następnych 90 byłoby ujawnione w księdze wieczystej.

59 Podsumowując: wzorcowe upoważnienie powinno być osobną pisemną listą imiennie (wraz z adresami) wskazanych podmiotów, którym bank zamierza udostępnić dane, z wyraźnym oświadcze- niem woli (podpisem) klienta, zaświadczającym, iż udziela on upoważnienia bankowi na przekazanie takich danych tym właśnie, a nie innym podmiotom. Pożądana byłaby również (zgodnie ze stanowiskiem KNB) klauzula, iż upoważnienie jest dobrowolne i brak zgody nie wyklucza zawarcia umowy. Zważywszy, iż są już powszechnie w użyciu klauzule dotyczące przetwarzania danych osobowych przez banki (w wykonaniu przepisów o ochronie danych osobowych), podpisywanie odrębnego upoważnienia będzie z pewnością budziło wątpliwości klientów.

60 Według zaś art. 32 ust. 6 małoletni, który ukończył 16 lat i dysponuje dostatecznym rozeznaniem, może wyrazić sprzeciw. Nasuwa się więc pytanie, czy brak zgody w przedstawionych wyżej sytua- cjach jest tożsamy ze sprzeciwem. Sądzę, że liczne wątpliwości, pojawiające się na tle tak tego, jak i innych przepisów ustawy, wynikają z niedociągnięć techniki legislacyjnej. Może to jednak powodo- wać poważne konsekwencje w postaci ograniczenia prawa autonomii woli pacjenta, gdyż wymaga- nej ustawowo zgody pominąć nie można, natomiast sprzeciw może zostać podważony przez orzecz-enia sądu opiekuńczego. Brak zgody nie jest zatem tożsamy ze sprzeciwem. /Anastazja Kołodziej - artykuł „Stopień autonomii woli pacjenta na tle ustawy o zawodzie lekarza i ustawy o ochronie zdro-wia psychicznego"/

\begin{tabular}{|l|l|l|c|c|}
\hline $\begin{array}{l}\text { brak } \\
\text { akce- } \\
\text { ptacji } \\
\text { nie }\end{array}$ & $\begin{array}{l}\text { Wyborcy i wybrani • Motywacje stojące u podstaw decyzji wyborcy są } \\
\text { więc często niewystarczają- ce dla uzasadnienia całościowego } \\
\text {,mandatu”, na który może powoływać się poseł. Sprawa kompli- kuje } \\
\text { się jeszcze bardziej, gdy partie -- już po wyborach - zawiązują koalicje, } \\
\text { by utworzyć większość i powołać rząd. Ktoś, kto głosował na SLD, } \\
\text { wcale nie musi akceptować programu PSL -- i na odwrót. Zresztą } \\
\text { ostatnie miesiące pokazuja, że taki brak akceptacji nie jest wyłącznie } \\
\text { teoretyczná hipotezą. Na ile rząd wyłoniony w wyniku utworzenia } \\
\text { takiej właśnie koalicji może wywodzić swą legitymację z woli } \\
\text { wyborców? }\end{array}$ & 0 & 1 \\
\cline { 2 - 5 } & $\begin{array}{l}\text { czym więc się przejmujemy ? my nie jesteśmy zerem !!! nie istniejemy } \\
\text { więc w materii, bo ona musi się zbilansować, a my się nie bilansujemy, } \\
\text { bo jako świadomość kreujemy w sobie poczucie bycia i egzystencji... } \\
\text { czy nie jest to właśnie rodzaj zatwardziałości naszej psychicznej } \\
\text { egzystencji ? wytwarzamy w sobie upartość bycia i brak akceptacji nie } \\
\text { bycia... i to tworzy z nas pasożyta materii ...ona bezbronna, uległa, a } \\
\text { może po prostu obojętna :) my wczepieni, zachłanni, ale za to z } \\
\text { nadzieją na uwolnienie się od niej : )) }\end{array}$ & 0 & 1 \\
\hline
\end{tabular}


63 Jakimkolwiek jednak byłby podmiot liryczny, doszedł on do niepodważalnej puenty tego wywodu. ,'Człowiek - jestem' musi żyć w zgodzie ze soba, bo brak akceptacji nie zrodzi w nim przecież nowego 'jestestwa'. Po prostu 'jest się jaki jest'" . /Artykuł o wierszach Mirona Białoszewskiego poświęconych leżeniu/

64 Jestem pod wrażeniem. „Oczywiście, że są, ale raczej $>>>$ nieporównywalne $<<<$ chociażby $\mathrm{z}$ tego względu, że w chrześcijaństwie i islamie brak jest choćby akceptacji dla dwulicowości" /poniżej to zdanie jest komentowane/ nie oznacza, że takie zjawisko nie istnieje. Np. śluby ubóstwa i celibat w chrześcijaństwie. O islamie z pokorą stwierdzę, że wiem za mało.

\section{Zestawienie wyników i wnioski}

Zestawienie wyników z tabeli 2 zamieszczono w tabeli 3. Wyniki ujęte w nawias należy tutaj czytać: w tym wypowiedzi dotyczacych prawa jest... .

Tabela 3

\begin{tabular}{|c|c|c|c|c|c|c|c|c|}
\hline \multirow{2}{*}{ typ } & \multirow{2}{*}{ zwroty (typy szczegółowe) } & \multicolumn{6}{|c|}{ liczba wypowiedzi typu logicznego: } & \multirow{2}{*}{ SUMA } \\
\hline & & + & $0 /+$ & - & $0 /-$ & 0 & $?$ & \\
\hline \multirow{4}{*}{ I } & Brak odmowy & $11(8)$ & 2 & & & & 3 & 16 \\
\hline & Brak zaprzeczenia & 1 & 1 & & & 2 & & 4 \\
\hline & Brak negacji & & & & & 9 & & 9 \\
\hline & SUMA & $12(8)$ & 3 & & & 11 & 3 & $29(8)$ \\
\hline \multirow{4}{*}{ II' } & Brak zgody (bez nie) & & & $7(4)$ & 1 & 1 & & $9(4)$ \\
\hline & Brak akceptacji (bez nie) & & & $2(1)$ & $16(1)$ & 6 & & $24(2)$ \\
\hline & Brak potwierdzenia (bez nie) & $\underline{\underline{1(1)}}$ & & $22(16)$ & & 1 & & $24(17)$ \\
\hline & SUMA & $1(1)$ & & $31(21)$ & $17(1)$ & 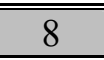 & & $57(23)$ \\
\hline \multicolumn{2}{|c|}{ SUMA DOTYCHCZASOWYCH SUM } & 14 14(9) & & $31(21)$ & $17(1)$ & 19 & 3 & $86(31)$ \\
\hline \multirow{4}{*}{ II" } & Brak zgody nie & & 3 & & & $6(2)$ & & $9(2)$ \\
\hline & Brak akceptacji nie & & & & & 4 & & 4 \\
\hline & Brak potwierdzenia nie & & & & & & & 0 \\
\hline & SUMA & & 3 & & & $10(2)$ & & $13(2)$ \\
\hline
\end{tabular}

W tabeli 2, dwa razy rozdzielono wypowiedzi podwójną linią, zgodnie z podziałem na trzy typy przedstawionym w tabeli 3 . W tabeli 4 zestawiono kwestie liczności tych typów oraz współczynnik korelacji znaczenia nazwy typu i wartości zawartych w nim wyników.

Wartość wyników liczy się w następujący sposób:

$>$ przyjmuje się: znak $=$ wartość, tj.: $+=1,0 /+=0,5,0=0,0 /-=-0,5, \quad-=-1$,

$>$ liczy się średnią ważoną dla poszczególnych typów, przy czym wyniki oznaczone „?” (ze względu na ich specyfikę) są pomijane.

Oto obliczenia poszczególnych parametrów korelacji:

A1 (dla typu II'): $[1 \cdot 1+31 \cdot(-1)+17 \cdot(-0,5)+8 \cdot 0] / 57 \approx-0,68$,

A2 (dla typu I): $\quad[13 \cdot 1+2 \cdot 0,5+11 \cdot 0] / 26 \approx 0,54$,

A3 (dla typu II''): $[3 \cdot 0,5+10 \cdot 0] / 13 \approx 0,12$.

Dodatkowo, w tabeli 4:

$>$ spodziewany znak to wartość tego, czego się autor niniejszego artykułu spodziewał się po nazwie typu,

$>$ współczynnik korelacji to iloczyn spodziewanego znaku (przyjmując: $+=+1,-=-1$ ) $\mathrm{i}$ parametru korelacji; mówi więc on, na ile rezultat analizy jest zbieżny z tym, czego 
teoretycznie się spodziewano $(+1=$ maksymalnie, $0=$ neutralnie, $-1=$ wynik całkiem odmienny od spodziewanego).

Tabela 4

\begin{tabular}{|c|l|c|c|c|c|}
\hline LP & \multicolumn{1}{|c|}{ typ } & $\begin{array}{c}\text { licz- } \\
\text { ność }\end{array}$ & $\begin{array}{c}\text { spodziewany } \\
\text { znak }\end{array}$ & $\begin{array}{c}\text { parametr } \\
\text { korelacji }\end{array}$ & $\begin{array}{c}\text { współczynnik } \\
\text { korelacji }\end{array}$ \\
\hline 1 & II' - brak pozytywnego & 57 & - & $-0,68(\mathrm{~A} 1)$ & 0,68 \\
\hline 2 & I - brak negatywnego & 29 & + & $0,54(\mathrm{~A} 2)$ & 0,54 \\
\hline 3 & II' - brak pozytywnego nie & 13 & + & $0,12(\mathrm{~A} 3)$ & 0,12 \\
\hline
\end{tabular}

Z analizy tabeli 4 wynika, że w każdym z trzech typów występuje dodatnia korelację, przy czym:

najbardziej jednoznaczna jest w przypadku typu „braku pozytywnego”,

$>$ trochę mniej w przypadku typu „braku negatywnego",

$>$ najmniej w przypadku typu „braku pozytywnego nie”.

Ponadto, w tabeli 4 poszczególne typy wymienione są zgodnie ze stopniem ich zrozumienia (od najłatwiejszego do najtrudniejszego) przez przeciętnego użytkownika języka. Dodatkowo wynikają stąd następujące 3 wnioski:

$>$ im coś jest łatwiejsze do zrozumienia, tym częściej się pojawia i odwrotnie (tj. łącznie: łatwość zrozumienia jest silnie dodatnio skorelowana z częstością pojawiania się),

$>$ im coś częściej się pojawia, tym bardziej jest regularne i odwrotnie (tj. łącznie: częstość pojawiania się jest silnie dodatnio skorelowana z regularnością),

$>\mathrm{z}$ przechodniości tych dwóch wniosków: im coś jest łatwiejsze do zrozumienia, tym bardziej jest regularne, i odwrotnie (tj. łącznie: łatwość zrozumienia jest silnie dodatnio skorelowana z regularnością).

W tabeli 2 pogrubieniem i podkreśleniem zaznaczono sytuację, która plasuje się po drugiej stronie od spodziewanej, a co za tym idzie, najbardziej wpływa na odchylenie wyniku rzeczywistego od spodziewanego. Dotyczy ona wypowiedzi nr 52:

$\mathrm{Na}$ życzenie klienta wysyłamy pisemne potwierdzenie przyjęcia zamówienia. potwierdzenia oznacza pełną akceptację zlecenia oraz jego realizację w sposób określony w zamówieniu (1 raz o wartości + ),

która - innymi słowy - orzeka, że:

Złożenie zamówienia jest wiqżace, bez względu na inne okoliczności ( $t j .-\mathrm{w}$ tym

przypadku - nieotrzymanie potwierdzenia ze względu na nieztożenie zlecenia).

W tabeli 5 należy zwrócić uwagę na wartości współczynnika korelacji (WK) dla wypowiedzi zawierających poszczególne zwroty, by zobaczyć, które z nich są najsilniejsze (najbardziej jednoznaczne i zarazem zgodne z przedstawionymi przez autora niniejszego artykułu przypuszczeniami, powodowanymi nazwą typu). 
Tabela 5

\begin{tabular}{|c|c|c|c|c|c|c|c|c|c|}
\hline \multirow{2}{*}{ Тур } & \multirow{2}{*}{$\begin{array}{l}\text { zwroty (typy } \\
\text { szczegółowe) }\end{array}$} & \multicolumn{6}{|c|}{ liczba wypowiedzi typu logicznego: } & \multirow{2}{*}{ SUMA } & \multirow{2}{*}{ WK } \\
\hline & & + & "0/+ & - & $0 /-$ & 0 & $?$ & & \\
\hline \multirow{4}{*}{ I } & Brak odmowy & $11(8)$ & 2 & & & & 3 & 16 & $0,92(1)$ \\
\hline & Brak zaprzeczenia & 1 & 1 & & & 2 & & 4 & 0,38 \\
\hline & Brak negacji & & & & & 9 & & 9 & 0 \\
\hline & SUMA & $12(8)$ & 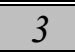 & & & 11 & 3 & $29(8)$ & $0,54(1)$ \\
\hline \multirow{4}{*}{ II' } & Brak zgody (bez nie) & & & $7(4)$ & 1 & 1 & & $9(4)$ & $0,83(1)$ \\
\hline & $\begin{array}{l}\text { Brak akceptacji (bez } \\
\text { nie) }\end{array}$ & & & $2(1)$ & $16(1)$ & 6 & & $24(2)$ & $0,42(0,75)$ \\
\hline & $\begin{array}{l}\text { Brak potwierdzenia } \\
\text { (bez nie) }\end{array}$ & $\underline{1(1)}$ & & $22(16)$ & & 1 & & $24(17)$ & $0,88(0,88)$ \\
\hline & SUMA & $1(1)$ & & $31(21)$ & $17(1)$ & 8 & & $57(23)$ & $0,68(0,89)$ \\
\hline \multirow{4}{*}{ II" } & Brak zgody nie & & 3 & & & $6(2)$ & & $9(2)$ & $0,17(0)$ \\
\hline & Brak akceptacji nie & & & & & 4 & & 4 & 0 \\
\hline & $\begin{array}{l}\text { Brak potwierdzenia } \\
\text { nie }\end{array}$ & & & & & & & 0 & - \\
\hline & SUMA & & 3 & & & $10(2)$ & & $13(2)$ & $0,12(0)$ \\
\hline
\end{tabular}

Tabela ta jest powtórzeniem tabeli 3 , jednak bez wiersza „suma dotychczasowych sum” i z nową kolumną (ostatnią) ze współczynnikami korelacji.

Wynika z niej, że wypowiedzi odnoszące się do prawa, zwykle są bardziej jednoznaczne (mają większe współczynniki korelacji) niż inne wypowiedzi danego typu.

Poniżej przedstawiono dokładny opis poszczególnych typów szczegółowych (analizując wypowiedzi z tabeli $2 \mathrm{i}$ ich zestawienie $\mathrm{z}$ tabeli 5).

\section{W ramach typu I}

Analizując tabelę 5, można stwierdzić, że typ szczegółowy „brak odmowy” ma współczynnik korelacji prawie równy 1 , „brak negacji” jest pod tym względem neutralny, a „brak zaprzeczenia”pośredni między nimi. Powodem tego jest dodatnia korelację z pospolitością słów odmowa (najbardziej pospolite), negacja (specjalistyczne) i zaprzeczenie (pośrednie pod tym względem).

Dodatkowo:

$>$ w ,braku odmowy”, wszystkie wypowiedzi prawne są typu logicznego +,

$>\mathrm{w}$,braku negacji”, wszystkie wypowiedzi są wyrazem subiektywnej oceny sytuacji (zob. tab. 2).

II. W ramach typu II'

Pospolitość (w sensie psychologicznym - w kolejności od najbardziej pospolitego do najbardziej specjalistycznego: zgoda, potwierdzenie i akceptacja) z powszechnością (w sensie liczbowym: najczęściej akceptacja i potwierdzenie, najrzadziej zgoda) nie idą w parze. Współczynnik korelacji jest tu jedynie $\mathrm{w}$ miarę zgodny $\mathrm{z}$ (opisanym $\mathrm{w}$ poprzednim zdaniu) aspektem pospolitości. $\mathrm{Z}$ aspektem powszechności jest on skorelowany ujemnie.

Dodatkowo na uwagę zasługują następujące spostrzeżenia:

$>$ prawie wszystkie wypowiedzi prawne są jednoznacznie oceniane jako - (za wyjątkiem sytuacji nr 52, gdzie akurat brak potwierdzenia oznacza petnq akceptacje, a więc mamy tam wartość + , oraz sytuacji 38, gdzie ze względu na aspekt b) z 2. paragrafu niniejszego artykułu, występuje jedynie wartość 0 /- a nie -),

$>$ wszystkie wypowiedzi typu „brak zgody to” (bez prawnej - nr 19), „brak akceptacji to” oraz „brak akceptacji jest” (znów bez prawnej - nr 33) są wyrazem subiektywnej oceny sytuacji (zob. tab. 2; można przyjąć je jako tworzące oddzielna kategorię) i w ramach wymienionych tu typów, zawsze są prawie tak samo oceniane (co do typu logicznego), 
to tu właśnie pojawia się przypadek nr 52, opisany przed tabelą $\mathrm{nr} 5$, jako jedyny $\mathrm{z}$ wypowiedzią plasującą się po drugiej stronie od spodziewanej (tj. o wartości + zamiast spodziewanej -).

III. W ramach typu II',

Te wypowiedzi są najbardziej neutralne i to nie tylko ze względu na średnią ( 0 można uzyskać z zestawienia $+z-$, a więc bez 0), ale i ze względu na ilość (głównie są zera!).

Spośród rozpatrywanych 3 typów: I, II' i II’, wypowiedzi tego typu jest najmniej. Ich łączna liczba to w przybliżeniu tyle, ile wynosi średnia liczebność zaledwie typów szczegółowych (podtypów) pozostałych dwóch typów.

W polskich zasobach Internetu w ogóle nie ma zdań z frazą „,brak potwierdzenia nie”.

Bardziej szczegółowego rozpatrzenia wymaga:

a) podtyp „brak potwierdzenia”, ze względu na częstość występowania tego typu sytuacji,

b) analiza wyróżnionych powyżej zdań będących wyrazem subiektywnej oceny sytuacji (ze względu na to, że tworzą integralnie niezależną kategorię, jak również ze względu na charakter tejże kategorii - subiektywne wypowiedzi są bardziej pojemne od obiektywnych - każdy może w nich wyrazić swoje zdanie, często różne od zdań innych osób),

c) kwestia, czy „brak A” to „nie-A”? (tj. czy np. „brak zgody” to „niezgoda”?).

Ad a)

W tabeli 5. „brak potwierdzenia” prawie zawsze daje odpowiedź negatywną (22 na 24 wypowiedzi), przy czym zawsze są to zdania - instrukcje postępowania (mówiące: jak nie potwierdzisz, to znaczy, że rezygnujesz) bądź (to jedynie w przypadku „brak potwierdzenia oznacza") objaśnienia lub wytłumaczenia danych sytuacji (jest to zrozumiałe, ze względu na trudność ze strony tzw. przeciętnego użytkownika języka w zrozumieniu zdań z negacją zawartą w słowie brak).

Wśród analizowanych zdań często wystapiła fraza „brak potwierdzenia”, jako że potwierdzenie często jest wymagane przy umowach (m.in. transakcjach) i w związku z tym wymaga się podania, czym skutkuje jego brak.

Ad b)

Poniżej przedstawiono, jakie wypowiedzi zostały zaliczone do kategorii wypowiedzi będących wyrazem subiektywnej oceny sytuacji, i co można z nich wywnioskować odnośnie znaczenia co one komunikują (wyniki zamieszczono w poniższej tabeli 6, w kolumnie „nr” występuje liczba z kolumny „LP” z tabeli 2).

\section{Tabela 6}

\begin{tabular}{|c|c|c|c|c|c|}
\hline typ & $\mathrm{Nr}$ & wypowiedzi (często skrócone w porównaniu z tabelą 2) & określenia & typ & $\begin{array}{l}\mathrm{Li} \\
\mathrm{cz} \\
\mathrm{ba}\end{array}$ \\
\hline \multirow{5}{*}{$\begin{array}{l}\text { brak } \\
\text { ne- } \\
\text { ga- } \\
\text { cji }\end{array}$} & 12 & Przecież brak negacj] niczego nie przesądza. & $\begin{array}{l}\text { niczego nie } \\
\text { przesądza }\end{array}$ & 0 & 2 \\
\hline & 13 & Korzyścią tego rozwiązania jest też brak negacj!! & jest korzystny & 0 & 2 \\
\hline & 14 & $\begin{array}{l}\text { Postrzegamy świat przez brak negacj; kategoria negacji } \\
\text { to częstość występowania sylaby nie- w wyrazach } \\
\text { pozytywnych /porady ogólne jak przemawiać/ }\end{array}$ & $\begin{array}{c}\text { jest sposobem } \\
\text { postrzegania przez } \\
\text { nas świata }\end{array}$ & 0 & 3 \\
\hline & 15 & $\begin{array}{l}\text { Brak negacji, poza stratą i zyskiem, brak pragnienia czy } \\
\text { przywiązania - taka jest medytacja }\end{array}$ & $\begin{array}{l}\text { jest elementem } \\
\text { medytacji }\end{array}$ & 0 & 1 \\
\hline & 16 & dwie negacje to brak negacji & $\begin{array}{l}\text { jest wynikiem } \\
\text { podwójnej negacji }\end{array}$ & 0 & 1 \\
\hline
\end{tabular}




\begin{tabular}{|c|c|c|c|c|c|}
\hline \multirow[t]{2}{*}{$\begin{array}{l}\text { brak } \\
\text { zgo- } \\
\text { dy }\end{array}$} & 17 & 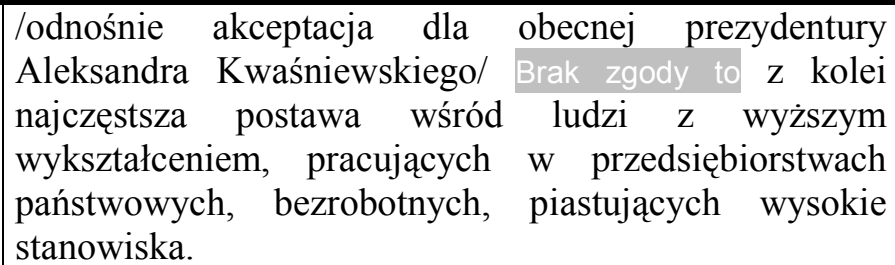 & $\begin{array}{l}\text { jest postawą } \\
\text { obywatelską }\end{array}$ & $0 /-$ & 1 \\
\hline & 18 & Jak brak zgody, to bez zgody /śródtytuł/ & jest konsekwentny & - & 1 \\
\hline \multirow[t]{7}{*}{$\begin{array}{l}\text { brak } \\
\text { ak- } \\
\text { cep- } \\
\text { tacji }\end{array}$} & 26 & $\begin{array}{l}\text { Brak dziękczynienia /Bogu/ oznacza brak akceptacji. A } \\
\text { brak akceptacj to odrzucenie. Kiedy odrzucamy kłopoty i } \\
\text { zmiany, odcinamy się od możliwości uzyskania Bożej } \\
\text { pomocy. Tylko akceptacja otwiera nam drzwi do Bożej } \\
\text { mądrości. To znaczy, tylko wtedy, gdy przyjmiemy } \\
\text { sytuację jako pochodzącą od Niego, Bóg natychmiast } \\
\text { pozwala nam zrozumieć sytuację, w której się } \\
\text { znaleźliśmy. }\end{array}$ & $\begin{array}{c}\text { oznacza } \\
\text { odrzucenie, a co } \\
\text { za tym idzie (ze } \\
\text { względu na } \\
\text { odcięcie się od } \\
\text { Bożej mądrości) - } \\
\text { brak zrozumienia } \\
\text { narzuconej nam } \\
\text { przez Niego } \\
\text { sytuacji }\end{array}$ & - & 1 \\
\hline & 27 & $\begin{array}{l}\text { /o rozważaniach nt sensu życia/ Wtedy możesz } \\
\text { skontaktować się ze swoim prawdziwym wewnętrznym } \\
\text { jestestwem i możesz zacząc dostrzegać, co jest } \\
\text { prawdziwe, co jest rzeczywiste. Co wymaga zmiany - a } \\
\text { co trzeba zostawić tak jak jest? Akceptacja jest tak } \\
\text { prosta - to przecież tylko opinia. Brak akceptacji to też } \\
\text { tylko opinia. JEST TAK JAK JEST. }\end{array}$ & jest tylko opinią & 0 & 3 \\
\hline & 28 & $\begin{array}{l}\text { Spróbuję trochę uporządkować sobie motywy } \\
\text { stosowania masek. Bo wielki wór pod tytułem brak } \\
\text { akceptaci" to taki ogólnik. }\end{array}$ & $\begin{array}{l}\text { jest pojęciem } \\
\text { ogólnym }\end{array}$ & 0 & 3 \\
\hline & 29 & $\begin{array}{l}\text { Jak myślicie z czego rodzą się kompleksy i jak sobie z } \\
\text { nimi radzić? Brak akceptacji jest głównym } \\
\text { prowodyrem....krytyka.....a o sposobach sama } \\
\text { chciałabym się czegoś dowiedzieć. }\end{array}$ & $\begin{array}{l}\text { jest głównym } \\
\text { powodem } \\
\text { kompleksów }\end{array}$ & $0 /-$ & 6 \\
\hline & 30 & $\begin{array}{l}\text { Wiele razy byłem świadkiem sytuacji, w których osoba } \\
\text { gorzej lub nawet inaczej ubrana padała ofiarą } \\
\text { zbiorowych drwin, przezwisk... Często nie potrafiła } \\
\text { „doczepić” się do towarzystwa. Nierzadko, przez } \\
\text { większość czasu pozostawała na uboczu. Taki brak } \\
\text { akceptacji jest normalny u zwierzątek popularnie } \\
\text { zwanych ludźmi. Patrzac na nich z perspektywy można } \\
\text { powiedzieć, że ich zachowanie jest bezsensowne. }\end{array}$ & $\begin{array}{l}\text { jako sytuacja } \\
\text { powszechna u } \\
\text { ludzi jest jednak } \\
\text { nienormalny }\end{array}$ & $0 /-$ & 1 \\
\hline & 31 & $\begin{array}{l}\text { Brak ostrożności jest błędem, ale brak życzliwości bywa } \\
\text { jeszcze większym. To rzucanie bumerangami. Myślę, że } \\
\text { bywają sytuacje gdy bycie nieżyczliwym jest konieczne, } \\
\text { że zdecydowany brak akceptacji jest nawet pewnego } \\
\text { rodzaju obowiązkiem, że nie ma czasu na coś inne, } \\
\text { bywają chwile kiedy trzeba podjąc szybkie decyzje. }\end{array}$ & $\begin{array}{l}\text { bywa } \\
\text { obowiązkiem, } \\
\text { który powinien } \\
\text { objawić się } \\
\text { brakiem } \\
\text { życzliwości }\end{array}$ & $0 /-$ & 2 \\
\hline & 32 & $\begin{array}{l}\text { Społeczny krytycyzm i brak akceptacji jest pogłębiany } \\
\text { rozpiętością ... między oczekiwaniami a ich } \\
\text { realizacją..., czyli przeświadczeniem, że „nie tak miało } \\
\text { być”. }\end{array}$ & $\begin{array}{l}\text { jest pogłębiany } \\
\text { rozpiętością } \\
\text { między } \\
\text { oczekiwaniami a } \\
\text { ich realizacją }\end{array}$ & $0 /-$ & 1 \\
\hline
\end{tabular}




\begin{tabular}{|c|c|c|c|c|}
\hline 34 & $\begin{array}{l}\text { Może Papież i Matka Teresa z Kalkuty to takie postacie, } \\
\text { że nikt nie miał wątpliwości, co do ich misji, nikt nie był } \\
\text { i nie jest przeciwko? Chociaż przeciwko Papieżowi jest } \\
\text { bardzo dużo osób, więc owa niechęć i niekiedy brak } \\
\text { akceptacji jest czymś, z czym po prostu trzeba się liczyć. }\end{array}$ & $\begin{array}{l}\text { ze względu na } \\
\text { powszechność jest } \\
\text { czymś, z czym } \\
\text { trzeba się liczyć }\end{array}$ & $0 /-$ & 1 \\
\hline 35 & $\begin{array}{l}\text { Zdaję sobie sprawę, że brak akceptacji dla dziecka } \\
\text { /poczętego/ jest wielkim dramatem i piekłem dla } \\
\text { kobiety. I to nie tylko problem teoretyczny. Ale mimo to } \\
\text { uważam, że ten brak akceptacji jest o wiele mniejszym } \\
\text { piekłem niż rozwiązanie ostateczne polegające na } \\
\text { uśmierceniu maleństwa. }\end{array}$ & $\begin{array}{c}\text { bywa } \\
\text { korzystniejszy } \\
\text { (dosłownie: ,,jest } \\
\text { mniejszym } \\
\text { piekłem”) }\end{array}$ & $0 /-$ & 1 \\
\hline 36 & $\begin{array}{l}\text { W każdym zawodzie konieczny jest jakiś rodzaj } \\
\text { akceptacji, szczególnie w takim, jak nasz, przecież } \\
\text { pracujemy dla publiczności, to ona nas akceptuje albo } \\
\text { nie. Dla aktora brak akceptacji jest ogromnie przykry, } \\
\text { wszystkie frustracje, stresy biorą się z jej braku, ze } \\
\text { świadomości, że się nie osiagnęło tego, co się } \\
\text { zamierzało, że w jakiś sposób zawiodło się i samego } \\
\text { siebie. }\end{array}$ & $\begin{array}{l}\text { jest ogromnie } \\
\text { przykry, gdyż } \\
\text { powoduje stresy i } \\
\text { frustracje }\end{array}$ & $0 /-$ & 2 \\
\hline 37 & Gorzej jest, gdy brak akceptacji jest raczej permanentny. & $\begin{array}{c}\text { jest niekorzystny, } \\
\text { gdy jest } \\
\text { permanentny }\end{array}$ & $0 /-$ & 1 \\
\hline
\end{tabular}

Z tabeli tej wynika, że zwykle „brak negacji” i „brak zgody” są postrzegane pozytywnie, a „brak akceptacji” - negatywnie. Po wszystkich tych wypowiedziach spodziewano się typu -, a są one typu: 0,0/- lub właśnie -, a więc wszystkie mają niedodatni współczynnik korelacji, co (w tym sensie) jest już zbieżne z przewidywaniami.

Ad c)

$\mathrm{Z}$ analizy wszystkich wypowiedzi z tabeli 2, wynika wniosek, że brak kategoryczności (oddany chociażby wypowiedzią nr 12: brak negacji niczego nie przesqdza) lepiej określa badane tu wypowiedzi niż kategoryczność (oddana np. wypowiedzią nr 16: dwie negacje to brak negacji). Zatem, podobnie jak ,pokój, to wcale nie brak wojny”, tak i w badanych tu wypowiedziach, brak jednego stanu (odmowy, zaprzeczenia, negacji, czy też zgody, akceptacji, potwierdzenia) niekoniecznie musi oznaczać (i przeważnie nie oznacza) bycia przeciwnego stanu.

Na uwagę zasługuje jeszcze fakt, że w wypowiedziach prawnych kategoryczność jest większa, ze względu na specyficzne wymogi prawa, to jest na konieczność dokonania właściwej interpretacji przepisów, a co za tym idzie mniejszej lub większej skuteczności w sporach prawnych. Dzięki tak pojętej kategoryczności wprowadza się bądź usuwa wątpliwości interpretacyjne.

\section{Bibliografia}

Austin, J. 1993. Mówienie i poznawanie (Philosophical Papers; How to Do Things with Words). Warszawa: PWN. Gleason, J.B., Raner, N.B, 2005. Psycholingwistyka. Gdańsk: Gdańskie Wydawnictwo Psychologiczne.

Habermas, J. 1997. Pojęcie racjonalności komunikacyjnej w świetle teorii aktów mowy. [W:] T. Buksiński (red.) Rozum i racjonalnść, Poznań: Wydawnictwo Naukowe Instytutu Filozofii UAM.

Lapis, W. 2006. Kategoria braku odpowiedzi w świadomości rozmówców. w: Investigationes Linguisticae XIV. Poznań. Str. 111-119.

Nachmias, D., Frankfurt-Nachmias Ch. 2001. Metody badawcze w naukach spolecznych. Poznań: Wydawnictwo Zysk i

Nagórko A., Zarys gramatyki polskiej, Warszawa 1996.

Satkiewicz, H., Buttler, D., Kurkowska, H. 1973. Kultura języka polskiego. Warszawa: PWN. 